\title{
Enzymatic semisynthesis of insulin specifically labelled with tritium at position B-30
}

\author{
J.Gwynfor Davies', Keith Rose, Charles G.Bradshaw and \\ Robin E.Offord \\ Département de Bıochımıe Médıcale, Centre Médıcal Universitaire, 9 \\ avenue de Champel, $\mathrm{CH}-1211$ Genève 4, Switzerland \\ ${ }^{1}$ To whom correspondence should be addressed
}

We have synthesized porcine insulin labelled with tritium at position B-30 using enzyme-catalysed formation of a peptide bond. The resulting insulin derivative has the label in the expected position and is biologically active. We have tested our procedure to prepare batches up to $50 \mu \mathrm{Ci}$ of tritiated insulin at a specific radioactivity of up to $1.14 \mathrm{Ci} / \mathrm{mmol}$. Key words: tritiated insulin/enzymatic semisynthesis

\section{Introduction}

Insulin plays an important role in the control of metabolism and is crucial to the treatment of certain types of diabetes mellitus. Such functions of insulin are influenced by processes that regulate the amount of biologically-active insulin in the circulation. Labelling of the insulin molecule with tritium has proved useful for studying these processes (Halban et al., 1976; Berger et al., 1978; Morishima et al., 1985; Davies et al., 1986; Muir et al., 1986). Labelling with tritium causes a minimal alteration to the hormone. Tritiated tracers labelled either at phenylalanine-B1 (Halban and Offord, 1975) or at glycine-Al (Davies and Offord, 1985) have been synthesized and shown to behave authentically (Halban et al., 1976; Morishuma et al., 1985; J.G.Davies, unpublished work). The labelled insulins mentioned above were produced semisynthetically, using chemical means to bnng about the essential steps of removal of an amino acid and its replacement by one that is tritiated. Chemical methods (which require the temporary protection of certain of insulin's functional groups) are readily applicable to alterations at the amino terminus of a peptide chain but are much more complicated to apply to substitution at the C-terminus. However, a carboxy-terminal labelled insulin is desirable; for example, in their experiments on the degradation of insulin, Muir et al. (1986) were unable to follow the fate of the carboxy-terminal portion of insulin once it had been cleaved from the labelled amino-terminal region.

The discoveries that proteases could be used not only to remove a part of a protein but also to catalyse its replacement in high yield by synthesis of peptide bonds, and that such syntheses are readily applicable to carboxy-terminal modifications, gave rise to the possibility of labelling insulin at position B-30 [see for example Rose et al. (1983) and references cited therein]. Temporary protection of functional groups of the protein is generally not required in such syntheses.

The purpose of this study was to synthesize and characterize insulin labelled with tritium at postion B-30 (Scheme 1). We found that satisfactory conditions for enzyme-catalyzed semisynthesis of small quantities of radioactive material were much more difficult to establish than for semisynthesis of non-radioactive derivatives, irrespective of scale. This difficulty with enzyme-

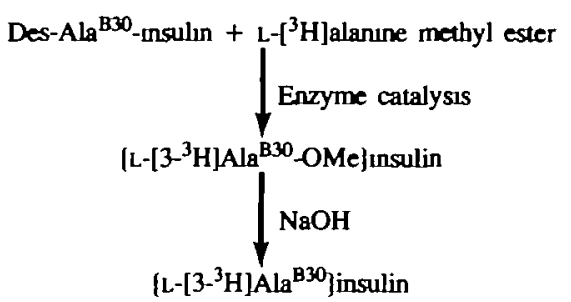

catalysed semisynthesis recalls that encountered earlier in effecting chemical ones at high specific activity (Davies, 1981). However, we describe below the successful use of the enzyme Achromobacter lyticus protease (Morihara et al., 1980) to synthesize a peptide bond between tritiated alanine methyl ester and des-Ala ${ }^{\mathrm{B} 30}$-insulin. The use of other enzymes for this synthesis is also discussed.

\section{Materials and methods}

All reagents and solvents, unless otherwise specified, were obtained from commercial sources, were of analytical grade or better and were used without further purification.

Monocomponent porcine insulin was purchased from Novo Industri, Copenhagen, Denmark. $\mathrm{L}-\left[3-{ }^{3} \mathrm{H}\right]$ alanine and $\left[\mathrm{U}-{ }^{14} \mathrm{C}\right]-$ glucose were obtained from New England Nuclear, Dreieich, FRG. Dimethylformamide was obtained from Merck and was redistilled before use, as described by Davies and Offord (1985). Carboxypeptidase A was from Sigma, St Louis, MO, USA. HPLC was performed on either of two systems, which have previously been described: (i) a Waters system (Rose et al., 1984), which has been modified by replacement of the manual injector with an automatic one (Wisp model 710B, Waters). On this system, solvent A was $1 \mathrm{~g}$ trifluoroacetic acid (h.p.l.c. grade, Pierce) dissolved in $11 \mathrm{HPLC}$-grade water (Milli-Q system), and solvent B was acetonitrile (LiChroSolv., Merck); (ii) a Beckman 344 gradient system (Davies and Offord, 1985). On this system solvent $\mathrm{A}$ was $100 \mathrm{ml} 3 \mathrm{M}\left(\mathrm{NH}_{4}\right)_{2} \mathrm{SO}_{4}$ adjusted to pH 2.7 with concentrated sulphuric acid and then made up to 1 l with HPLC-grade water. Solvent B was $100 \mathrm{ml} 3 \mathrm{M}$ $\left(\mathrm{NH}_{4}\right)_{2} \mathrm{SO}_{4}$ adjusted to $\mathrm{pH} 2.7$ with concentrated sulphuric acid, mixed with $350 \mathrm{ml}$ acetonitrile (LiChroSolv., Merck) and then made up to 11 with HPLC-grade water. Because of the phenomenon of electrocontraction, it is important to mix thoroughly before the addition of the last few millilitres of water. The column was a $250 \times 4.6 \mathrm{~mm}$ RP18 Spheri-5 from Brownlee Labs. USA.

Determination of radioactivity in solution was carried out in Biofluor or Aquasol scintillation cocktails (New England Nuclear, Boston, MA, USA) with a Beckman LS6800 liquid scintillation counter. Radioactivity on paper electropherograms was determined by a Berthold windowless Linear Analyser.

Purification of $L-\left[3-{ }^{3} H\right]$ alanine

The radioactive amino acid $(3.5 \mathrm{mCi}, 41 \mathrm{nmol}$ at $85 \mathrm{Ci} / \mathrm{mmol})$, diluted to a nominal $2 \mathrm{Ci} / \mathrm{mmol}$ by the addition of $1.7 \mu \mathrm{mol} \mathrm{L}$ alanine and lyophilized, was purified from non-radioactive, u.v.- 
absorbing (214 nm) material by HPLC (Waters system). The sample was dissolved in $210 \mu \mathrm{l} 1.2 \mathrm{mM} \mathrm{HCl}$ and of this, $200 \mu \mathrm{l}$ were injected onto a reversed-phase column $(220 \times 4.6 \mathrm{~mm}$ with a 30-mm guard column, Spheri-5 RP18, Brownlee Labs.) equilibrated and eluted isocratically at $1 \mathrm{ml} / \mathrm{min}$ with solvent $\mathrm{A}$. Effluent was pooled in the period between 3 and $5 \mathrm{~min}$ after the injection of the sample which corresponds to the elution position of alanine as determined with a standard. After washing the column with $10 \%$ solvent $B$ and re-equilibrating with solvent $A$, a second run was made with $200 \mu$ lube washings, pooling the column effluent as before. Recovery of alanine, on the basis of radioactivity, was $91 \%$.

Synthesis of $L-\left[3-{ }^{3} H\right]$ alanine-methyl ester

After lyophilization, the radioactive amino acid from the previous step was esterified with $0.5 \mathrm{ml} 5.3 \mathrm{M} \mathrm{HCl}$ in dry methanol at room temperature overnight. T.l.c. (Polygram Sil N-HR silica plates, Macherey-Nagel and Co., Duren, FRG) in butan-1-ol/acetic acid/water/pyridine (30:6:24:20 by vol.) showed more than $99 \%$ conversion to ester as judged by radioactivity (Berthold Linear Analyser). Reagent and solvent were evaporated under a stream of nitrogen. Determination of radioactivity in small volumes of volatile solvents is difficult, and thus the recovery was not estimated at this stage.

\section{Enzyme-assisted coupling}

Des-Ala ${ }^{\mathrm{B} 30}$-insulin was prepared essentially according to Morihara et al. (1980). In a mixture of $0.5 \mathrm{M}$ solutions of sodium acetate and of acetic acid, both in butane-1,4-diol/water $9: 1(\mathrm{v} / \mathrm{v})$, a $10 \mathrm{mM}$ solution of des- $\mathrm{Ala}^{\mathrm{B} 30}$-insulin was prepared, which registered $\mathrm{pH} 7.0$ at the uncorrected glass electrode. To the dry radioactive amino acid methyl ester was added $49 \mu \mathrm{l}$ of the des$\mathrm{Ala}^{\mathrm{B} 30}$-insulin solution, followed by $1.75 \mu \mathrm{l}$ (acceptable limits, $\pm 0.1 \mu \mathrm{l}$ ) of a solution of A.lyticus protease (Lysyl endopeptidase, Wako Pure Chemical Co.), $50 \mu \mathrm{g} / \mathrm{ml}$ in water. After incubation for $2 \mathrm{~h}$ at $22^{\circ} \mathrm{C}$ the reaction mixture was quenched with $50 \mu \mathrm{l}$ acetic acid, followed by $100 \mu \mathrm{l}$ water.

\section{Isolation of $\left(L-\left[3^{3}{ }^{3} \mathrm{H}\right] \mathrm{Ala}^{\mathrm{B}{ }^{30}}\right.$-OMe $\}$ insulin}

The quenched coupling mixture was chromatographed in three portions on the Waters system. The column, a C18 Radialpak $\mu$-Bondapak cartridge in a Z-module, was equulibrated and then eluted with $25 \%$ solvent $B$ at $1 \mathrm{ml} / \mathrm{min}$. After $5 \mathrm{~min}$, a linear gradient of $+0.2 \%$ solvent $B / \mathrm{min}$ was applied for a further $50 \mathrm{~min}$. Under these conditions, des- $\mathrm{Ala}^{\mathrm{B} 3}$-insulin and porcine insulin B30-methyl ester, made as previously described (Rose et $a l ., 1983$ ), elute at retention times of 39 and $42 \mathrm{~min}$ respectively. The solvent fronts were pooled for recovery of the radioactive alanine methyl ester. The radioactive protein peaks (insulin methyl ester) were pooled, and the solvent was removed in a vacuum centrifuge (Speed-Vac, Savant Instruments, Hicksville, USA).

\section{Deprotection of $\left[L-\left[3-{ }^{3} H\right] A l a^{B 30}\right.$-OMe $\}$ insulin}

The $\left[\mathrm{L}-\left[3-{ }^{3} \mathrm{H}\right] \mathrm{Ala}^{\mathrm{B} 30}-\mathrm{OMe}\right]$ insulin was redissolved in $50 \mu \mathrm{ldi}$ methylformamide/water $1: 1(\mathrm{v} / \mathrm{v})$ and cooled to $0^{\circ} \mathrm{C}$ on ice. This corresponds to $4.4 \mathrm{mg} / \mathrm{ml}$ estimated on the basis of the radioactivity and assuming a nominal $2 \mathrm{Ci} / \mathrm{mmol}$. Fifty microlitres of $1 \mathrm{M} \mathrm{NaOH}$, which had been previously cooled on ice, were added and after $20 \mathrm{~s}$ on ice, $25 \mu \mathrm{l}$ glacial acetic acid were added. The reaction mixture was then applied directly to reversedphase HPLC (Beckman system). The column was a Brownlee RP18 Spheri-5, equilibrated and eluted with a percentage of solvent $B$ such that insulin elutes with a retention time of $\sim 10 \mathrm{~min}$ at a flow of $1 \mathrm{ml} / \mathrm{min}$ (actual conditions: $69 \% \mathrm{~B}$, retention time of porcine insulin $=10.2 \mathrm{~min}$ ). Under equivalent conditions, insulin had been shown to separate from $\left[\mathrm{Ala}^{\mathrm{B} 30}-\mathrm{OMe}\right]$ insulin, which eluted with a retention time 1.6 times greater than that of insulin. The pooled insulin peak was then applied to a Seppak C18 cartridge (Waters) previously equilibrated in acetonitrile/water/trifluoroacetic acid 20:80:0.1 (by vol.) and washed with $20 \mathrm{ml}$ of the same solvent mixture. The insulin was eluted from the cartridge with $4 \mathrm{ml}$ acetonitrile/water/trifluoroacetic acid 40:60:0.1 (by vol). The acetonitrile was removed by evaporation with a stream of filtered compressed air and the resultung solution lyophilized. The sample was resuspended in $0.5 \mathrm{ml}$ $0.14 \%$ (w/v) $\mathrm{CH}_{3} \mathrm{COONa} / 0.7 \%$ (w/v) $\mathrm{NaCl}$ and dissolved by the careful addition of powdered solid Tris base of $\mathrm{pH}$ 8.5. The solution was then saturated with the bacteriostat $p$-methylbenzoic acid and sterilized by filtration through a Sartorius $0.2 \mu \mathrm{m}$ cellulose acetate filter (SM 11107). Samples were removed for determination of the radioactivity and other types of characterization. The solution was stored at $4^{\circ} \mathrm{C}$.

\section{Characterization}

Reversed-phase HPLC. $\left(\mathrm{L}-\left[3^{3}{ }^{3} \mathrm{H}\right] \mathrm{Ala}^{\mathrm{B}}{ }^{\mathrm{3}}\right\}$ insulin $(0.05 \mu \mathrm{Ci})$ was mixed with $10 \mu \mathrm{g}$ of unlabelled porcine insulin and injected onto reversed-phase HPLC (Beckman system with a Brownlee RP18 Spheri-5 column). The insulin was eluted isocratically at $1 \mathrm{ml} / \mathrm{min}$ with $71 \%$ solvent $B$ for $15 \mathrm{~min}$ and a linear gradient of $+14.5 \%$ solvent $\mathrm{B} / \mathrm{min}$ was then applied to $100 \%$ solvent $\mathrm{B}$. The effluent was collected in 0.5 -min fractions and $0.2-\mathrm{ml}$ aliquots taken for determination of radioactivity.

Separation of the axidized insulin chains. $\left\{\mathrm{L}-\left[3-{ }^{3} \mathrm{H}\right] \mathrm{Ala}{ }^{\mathrm{B} 30}\right\}$ insulin $(0.05 \mu \mathrm{Ci})$ was mixed with $100 \mu \mathrm{g}$ unlabelled porcine insulin and lyophilized. The sample was redissolved in $9 \mu \mathrm{l}$ formic acid and $1 \mu \mathrm{l}$ hydrogen peroxide ( $30 \%$ in water) was added to oxidize the disulphide bonds. After $8 \mathrm{~min}$ at room temperature the reaction was quenched by the addition of $0.5 \mu \mathrm{l} 0.2 \mathrm{M} \mathrm{NaHCO}_{3}$. The resultung solution was injected onto reversed-phase HPLC (Beckman system, Brownlee RP18 Sphen-5 column) equilibrated with $28.6 \%$ solvent B (10\% acetonitrile) and a gradient of $+4.76 \%$ solvent $\mathrm{B} / \mathrm{min}(+1 \%$ acetonitrile $/ \mathrm{min}$ ) applied to $100 \%$ solvent B (35\% acetonitrile), flow rate $1 \mathrm{ml} / \mathrm{min}$. Fractions were collected every $0.2 \mathrm{~min}$ and the radioactivity in each determined. Cleavage of $\left(L-\left[3-{ }^{3} H\right] A l a^{B 30}\right\}$ insulin with Armillaria mellea protease. This protease [isolated by the method of Gregory and Walton (1976) from mushrooms growing in western Switzerland and neighbouring regions of France] cleaves specifically at the peptide bond on the amino-terminal side of lysine residues. As the only lysine residue in insulin is at position B-29, this enzyme releases the peptide Lys-Ala from porcine insulin. $\left\{\mathrm{L}-\left[3-{ }^{3} \mathrm{H}\right] \mathrm{Ala}{ }^{\mathrm{B} 30}\right\}$ insulin $(0.05 \mu \mathrm{Ci})$ was added to $50 \mu \mathrm{g}$ unlabelled porcine insulin already dissolved in $5 \mu \mathrm{l} 2.5 \%(\mathrm{w} / \mathrm{v})$ $\mathrm{NH}_{4} \mathrm{HCO}_{3}$. To this solution were added $8 \mu \mathrm{l}$ water and after warming to $37^{\circ} \mathrm{C}, 1 \mu \mathrm{l} \mathrm{A}$.mellea protease in water (the protease is active in very dilute solutions and so the exact enzyme concentration was unknown; trial experiments had shown this volume to be required). After $4 \mathrm{~h}$ at $37^{\circ} \mathrm{C}$ the sample was loaded onto Whatman 3MM paper and dried under high vacuum. The peptide Lys - Ala was separated from the cleaved protein by paper electrophoresis at $\mathrm{pH} \mathrm{6.5,} \mathrm{the} \mathrm{radioactivity} \mathrm{detected} \mathrm{with} \mathrm{a} \mathrm{Ber-}$ thold Linear Analyser and the peptide and protein detected by staining with ninhydrin-cadmium (Offord, 1969). Mobility ( $m$ ) was determined with respect to aspartic acid.

Specific radioactivity. The specific radioactivity of the $\left\{\mathrm{L}-\left[3-{ }^{3} \mathrm{H}\right] \mathrm{Ala}{ }^{\mathrm{B} 30}\right\}$ insulın was determined by comparison of the area under the insulin peak obtained by reversed-phase 

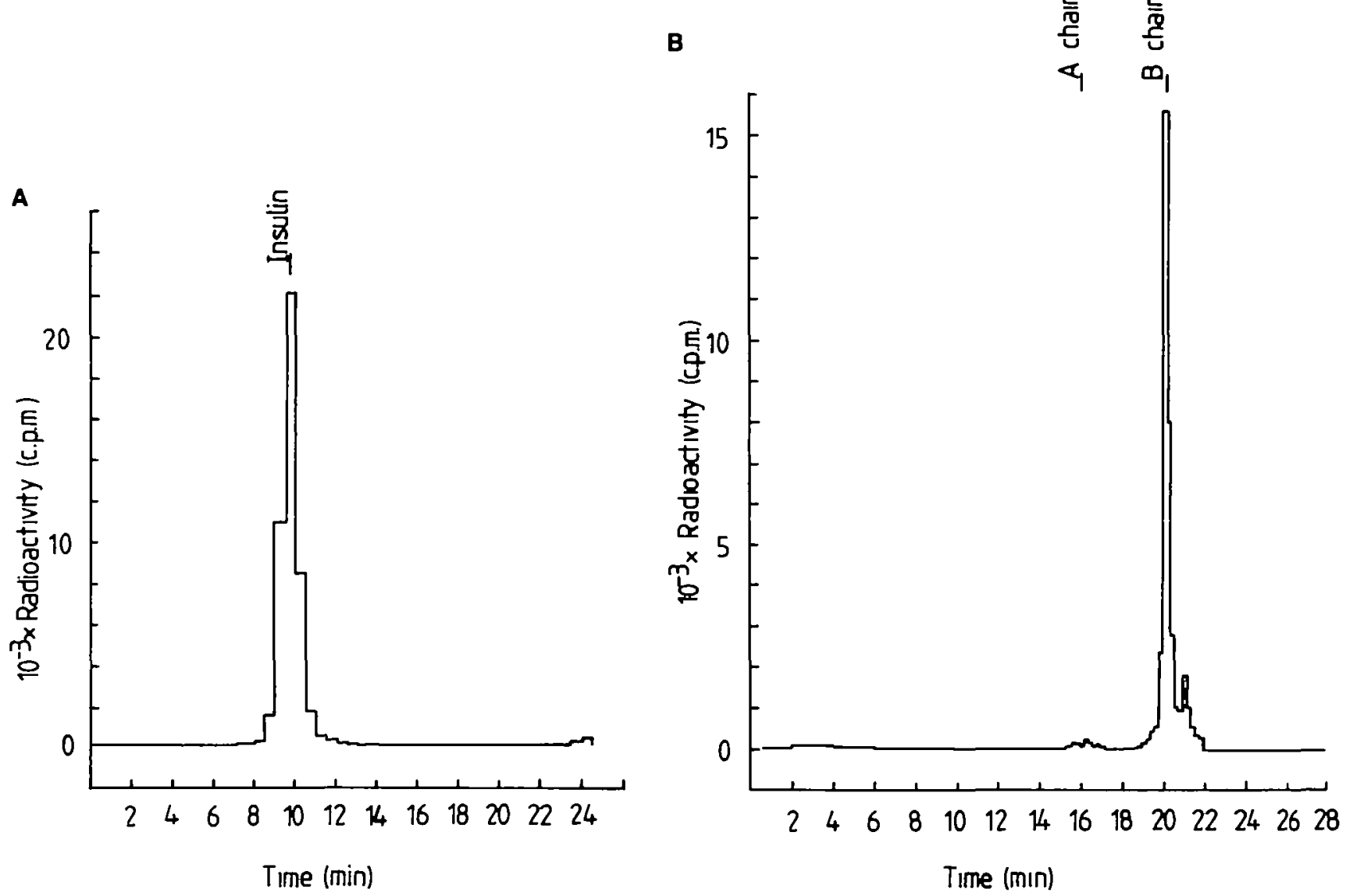

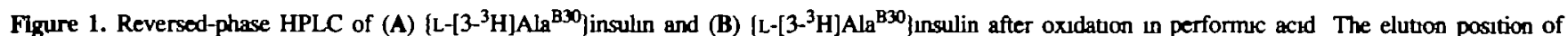
standards detected by absorption at $214 \mathrm{~nm}$ is indicated The munor peak eluting after the main B-chain peak in B is also present in the profile of absorbance at $214 \mathrm{~nm}$ This peak was taken to represent oxdized B-chain which had been further modified by the performic acid, since its size increases whth tume of oxidation as that of the major B-chan peak decreases (data not shown). Both analyses were carned out on the Beckman system. The unoxidized insulin (A) was eluted under isocratic condruons at $71 \%$ solvent B followed by a gradient to $100 \%$ solvent $B$. The oxhdrzed insulun was eluted with a gradient of $+4.76 \%$ solvent $\mathrm{B} / \mathrm{min}(+1 \%$ acetonitrile/min) from $286 \%$ solvent $\mathrm{B}$ (10\% acetonitrle) to $100 \%$ solvent $\mathrm{B}$ (35\% acetonitrie).

HPLC of this material with that of a standard porcine insulin solution. The quantity of insulin present in $10 \mu \mathrm{l}$ of the $\left\{\mathrm{L}-\left[3^{3}{ }^{3} \mathrm{H}\right] \mathrm{Ala}{ }^{\mathrm{B} 30}\right]$ insulin solution was calculated from the concentration of radioactivity assuming a specific radioactivity of $2 \mathrm{Ci} / \mathrm{mmol}$. A standard solution of porcine insulin was adjusted to this concentration on the basis of its absorbance at $280 \mathrm{~nm}$ and five injections of $10 \mu \mathrm{l}$ each made on the Beckman HPLC, Brownlee RP18 Speri-5 column, gradient 57.1-100\% B $(20-35 \%$ acetonitrile) over $15 \mathrm{~min}$ at $1 \mathrm{ml} / \mathrm{min}$. The area under the insulin peak at $214 \mathrm{~nm}$ was calculated in each case and the mean value calculated $(S)$. Ten microlitres of the $\left\{\mathrm{L}-\left[3-{ }^{3} \mathrm{H}\right] \mathrm{Ala}{ }^{\mathrm{B} 30}\right\}$ insulin solution were then injected and the area under the insulin peak also calculated $(A)$. The true sp. act. was then calculated as $2 \times S / A \mathrm{Ci} / \mathrm{mmol}$.

Biological characterization. The biological activity of the $\left\{\mathrm{L}-\left[3^{-} \mathrm{H}\right] \mathrm{Ala}^{\mathrm{B} 30}\right\}$ insulin was tested as the stimulation of incorporation of $\left[\mathrm{U}-{ }^{14} \mathrm{C}\right]$ glucose into lipid in isolated rat fat cells by the method of Moody et al. (1974).

Cleavage with carboxypeptidase $A$. The tritiated alanine was cleaved from the radioactive insulin molecule with carboxypeptidase A by the method of Schmitt and Gattmer (1978), with minor modifications. Carboxypeptidase $\mathrm{A}$ was treated as described by Offord (1980). Fifty microlitres $(2.73 \mu \mathrm{Ci}$ or $2.4 \mathrm{nmol}$ at $1.14 \mathrm{Ci} / \mathrm{mmol}) \quad\left(\mathrm{L}-\left[3-{ }^{3} \mathrm{H}\right] \mathrm{Ala}^{\mathrm{B} 30}\right\}$ insulin was lyophilized and redissolved in $10 \mu \mathrm{l} 0.1 \mathrm{M}$ ammonium bicarbonate. Carboxypeptidase $\mathrm{A}(10 \mathrm{mU})$ was added in $1 \mu \mathrm{l} 2 \mathrm{M}$ ammonium bicarbonate and the reaction left at room temperature for $16 \mathrm{~h}$. The products of this reaction were passed through a Sep-pak cartridge previously equilibrated in water/trifluoroacetic acid 100:0.1 (v/v). The cartridge was then washed with a further $20 \mathrm{ml}$ of this solvent. Aliquots were removed for the determination of radioactivity. The eluant fractions, containing cleaved tritiated alanine which does not bind to the Sep-pak under these conditions, were pooled and lyophilized. Two millilitres of water/acetonitrile/trifluoroacetic acid 60:40:0.1 (by vol.) were then passed through the Sep-pak to remove the des-Ala-insulin and any uncleaved insulin, and aliquots of this eluant removed for determination of the radioactivity. The lyophilized material was resuspended in $250 \mu \mathrm{l}$ of a standard mixture containing $10 \mathrm{nmol} / \mathrm{ml}$ of each of 18 amino acids. Fifty microlitres were applied to an amino acid analyser and the quantity of alanine determined relative to the standard mixture on its own, using methionine (which is not present in porcine insulin) as an internal standard. Three aliquots of $50 \mu \mathrm{l}$ were removed for determination of the radioactivity in the solution applied to the amino acid analyser. This value, together with the quantity of alanine cleaved from the tritiated insulin by carboxypeptidase $A$, was then used to calculate the sp. act. of the tritiated alanine in the radioactive insulin preparation. 


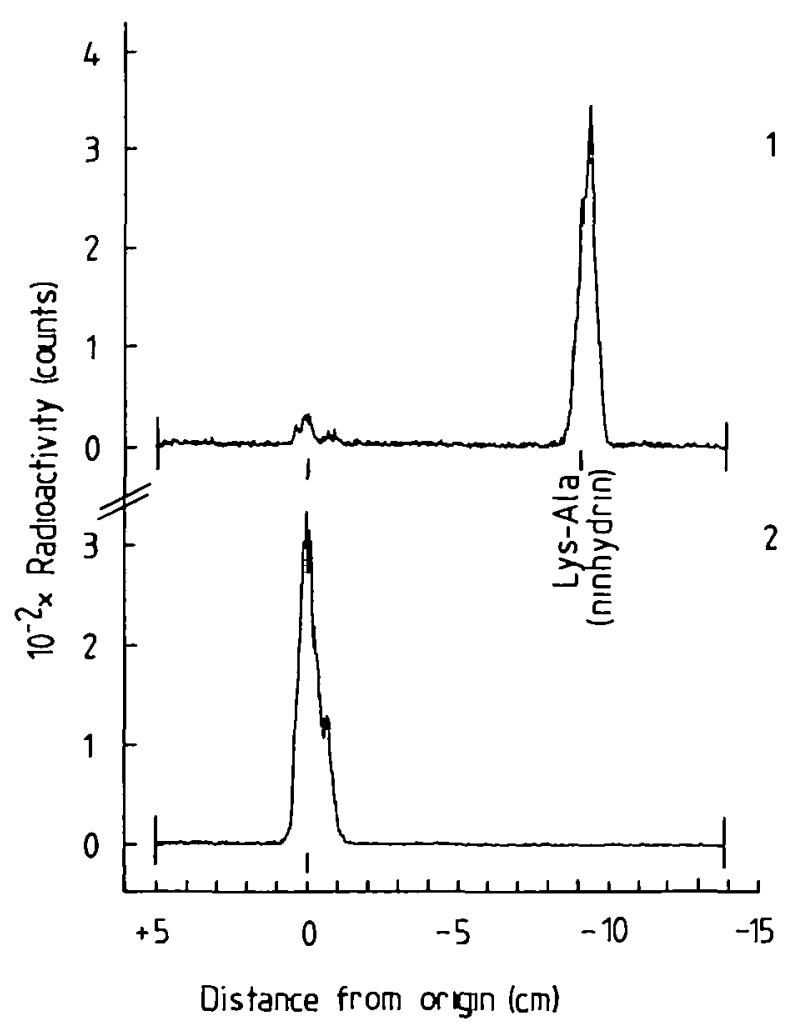

Figure 2. Paper electrophoresis of the result of cleavage of [L- $\left.\left[3-{ }^{3} \mathrm{H}\right] \mathrm{Ala}^{3{ }^{30}}\right]$ insulin with Amillaria mellea protease Radroactuvity was detected by a Berthold Linear Analyser. The peptide Lys-Ala, which is released from the carboxy-termunus of the insulin B-chan by this enzyme, was detected by stanning with ninhydran-cadmuum (predicted $m=072$, observed $m=0.7)$. (1) $\left\{\mathrm{L}-\left\{3-{ }^{3} \mathrm{H}\right] \mathrm{Ala}{ }^{\mathrm{B} 30}\right\}$ insulun after treatment with enzyme, (2) $\left\{\mathrm{L}-\left[3-{ }^{3} \mathrm{H}\right] \mathrm{Ala}{ }^{\mathrm{B} 30}\right]$ insulin

\section{Results and discussion}

\section{Enzyme-assisted coupling}

Very high coupling yields, based on protein substrate, may be obtained under conditions of thermodynamic control when using a large excess of a nucleophile [see e.g. Rose et al. (1983)]. In the case of an expensive nucleophile, and in particular a radioactive one, it is neither possible nor desirable to work with large volumes of concentrated reagent. For this reason, we performed preliminary experiments in which we varied the concentration of both des-Ala ${ }^{\mathrm{B} 30}$-insulın and alanine methyl ester (unlabelled or $<<2 \mathrm{Ci} / \mathrm{mmol}$ ). The results (data not shown) indicated that to obtain maximum yield with respect to alanine methyl ester, the des- $\mathrm{Ala}^{\mathbf{B} 3}$-insulin concentration should be as high as possible in the range tried (up to $10 \mathrm{mM}$, close to the limit of solubility). Also the alanine methyl ester concentration should be as low as possible in the range tried (down to $30 \mathrm{mM}$ ). With the amino acid ester at $30 \mathrm{mM}$, equilibrium yrelds of coupled product were $\sim 20 \%$ based on des-Ala ${ }^{\mathrm{B} 30}$-insulin ( $\sim 7 \%$ based on amino acid ester). Since both the preparation of truncated polypeptide precursors and the coupling reaction itself are very simple to carry out compared to what is necessary to prepare $\left[\mathrm{L}\left[{ }^{3} \mathrm{H}\right] \mathrm{Gly}{ }^{\mathrm{Al}}\right\}$ insulin (Davies and Offord, 1985) and $\left\{\mathrm{L}\left[{ }^{3} \mathrm{H}\right] \mathrm{Phe}^{\mathrm{BI}}\right\}$ insulin (Halban and Offord, 1975), a rather low radiochemical yield is not a great problem: the label can in principle be recycled.

\section{Deprotection and purification}

Insulin is know to withstand the relatively harsh conditions used for the removal of methylsulphonylethyloxycarbonyl (Msc)

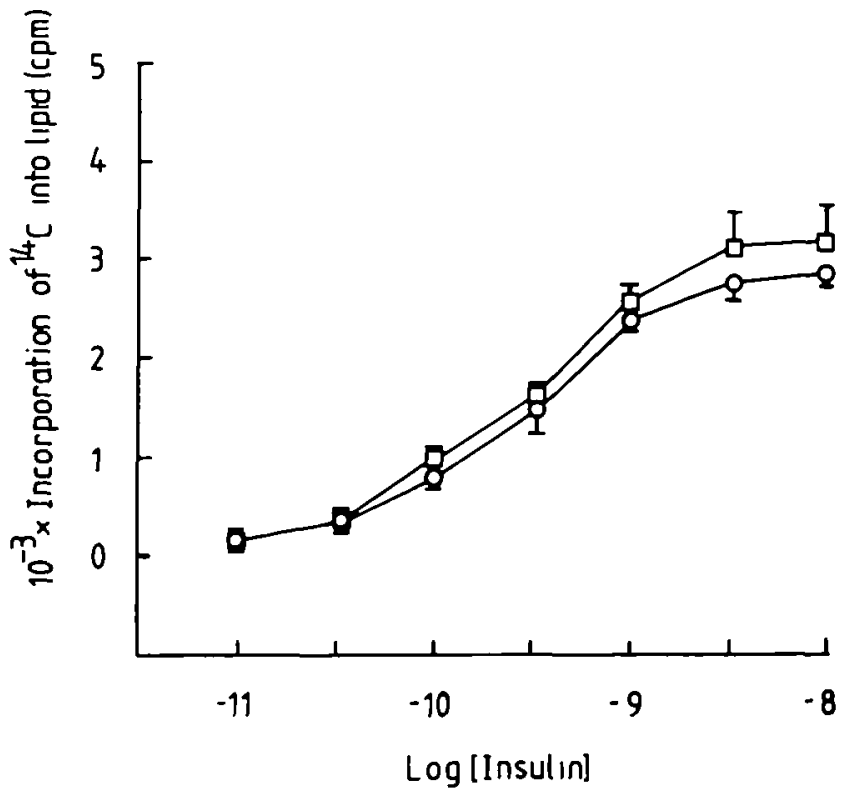

Figure 3. Stumulation of incorporation of $\left[\mathrm{U}^{14} \mathrm{C}\right]$ glucose into lipid in isolated rat fat cells Unlabelled insulin $(\mathrm{O}-\mathrm{O}),\left\{\mathrm{L}-\left[3-{ }^{3} \mathrm{H}\right] \mathrm{Ala}{ }^{\mathrm{B} 30}\right]$ insulin $(\square-\square)$ Results are the means of three of four observations at each concentration of insulin or derivative, with the standard deviation

groups (Geiger et al., 1975; Davies and Offord, 1985). We therefore chose these conditions for the saponification of the methyl ester group at position B-30. Reversed-phase HPLC (Beckman system) showed that $75 \%$ or more of the ester was hydrolyzed. In addition only $2 \%$ of the radioactivity eluted at the column breakthrough indicating that loss of tritium from the amino acid residue is not a major problem. The yield after deprotection was $2.2 \%$ based on recovery of radıactivity from the $3.5 \mathrm{mCl}$ used at the outset. At $1.14 \mathrm{Ci} / \mathrm{mmol}$ (see Characterization below) this gives a yield of $13 \%$ of the protein present in the coupling reaction. The final yield was $1.5 \%$ based on radioactivity and $9.4 \%$ on the basis of protein.

\section{Characterization}

( $\mathrm{L}-\left[3-{ }^{3} \mathrm{H}\right] \mathrm{Ala}{ }^{\mathrm{B} 30}$ ) insulin behaves as unlabelled insulin on isocratic elution from reversed-phase h.p.l.c. (Figure 1A). The tritiated insulın was cleaved chemically and enzymatically to investigate the position of the label on the molecule. Thus, after oxidation in performic acid, $94.7 \%$ of the radioactivity was associated with the B-chain on reversed-phase HPLC (Figure 1B). The chemical nature of the remainıng radioactivity was not determıned, but $1.7 \%$ eluted at the column breakthrough, $3.0 \%$ on the gradient before the oxidized B-chain (probably representing partially oxidized insulin) and a further $0.6 \%$ after the B-chain. Following cleavage of the tritiated insulin with A.mellea protease, paper electrophoresis showed that $92 \%$ of the radioactivity was associated with the peptide Lys - Ala, the carboxy-terminal dipeptide of the B-chain. The remaining radioactivity stays at the electrophoretic origin as does all the label in a control where enzyme was not added to the insulin (Figure 2).

The concentration of the tritiated insulin was determined by reversed-phase HPLC. The sp. act. thus calculated was 1.14 $\mathrm{Ci} / \mathrm{mmol}$ rather than the nominal $2 \mathrm{Ci} / \mathrm{mmol}$ to which the tritiated alanine had been diluted at the outset. We therefore determined the specific radioactivity of the alanine which was present at position B-30 in the tritiated insulin. Carboxypeptidase A cleavage of the alanine and subsequent passage through a Sep-pak car- 
tridge showed that $96 \%$ of the radioactivity was removed from the insulin by this treatment. Subsequent amino acid analysis showed that the specific radioactivity of the tritiated alanine was $1.17 \mathrm{Ci} / \mathrm{mmol}$. This value is essentially the same as that of the tritiated insulin indicating that there is no major contamination with des-Ala ${ }^{\mathrm{B} 30}$-insulin. The discrepancy from the nominal value of $2 \mathrm{Ci} / \mathrm{mmol}$ could have arisen from the fact that the tritiated alanine as purchased contained volatile radioactive contaminants or exchangeable tritium on some atom other than C-3. In addition the possibility of an unfavourable secondary isotope effect operating during the coupling step cannot be ruled out. The specific biological activity of the tritiated insulin resembles that of a standard porcine insulin (Figure 3).

\section{Alternative enzymes}

Whilst an acceptable yield of product may be obtained with $A$. lyticus protease, other enzymes which are known to catalyse such reactions have proved to be less useful. Carboxypeptidase $Y$, used under fully aqueous conditions with insulın B30-amide and alanine amide as substrates, gave side products (not characterized) which were difficult to separate from the desired product and yields were low. Bovine trypsin (known to be less robust than the porcine form) appears to be very sensitive to the coupling reaction conditions, possibly due to the production of free radicals by the interaction of the radiation with the solvents: yields are high with unlabelled amino acid esters but become unacceptably low when the alanine is tritiated. However, porcine trypsin is much more resistant to the coupling conditions and yields in the presence of this enzyme were almost as high as with A.lyticus protease.

\section{Conclusion}

We have prepared tritiated insulin specifically labelled at position B-30. The specific activity of this insulin tracer is sufficient to carry out studies in vitro and in vivo on insulin processing. Measurable quantities of radioactivity are present at high physiological concentrations with this sp. act.: $1 \mathrm{nM}$ insulin would give $\sim 2000$ d.p.m./ml. Higher specific activities are sometumes preferable (Davies and Offord, 1985), as they allow work at lower insulin concentrations, and are theoretically possible since the original labelled amino acid can be purchased at up to 85 $\mathrm{Ci} / \mathrm{mmol}$. The cost may become the deciding factor as scalıng down the synthesis to give a coupling volume of less than $10 \mu \mathrm{l}$ is not recommended.

\section{Acknowledgements}

We thank the Fonds National Suisse de la Recherche Scientufique for financial support We also thank the Schmidheiny Foundation for the purchase of equipment for h.p.l.c.

\section{References}

Berger,M , Halban,P.A , Muller,W A , Offord,R.E., Renotd,A.E. and Vranı, M. (1978) Drabetologia, 15, 133-140

Davies,J G. (1981) Suidies on proteolytuc fragments of clinical interest. the semssynthesis of trituated insulin and the analysis of its fragments D.Phul. thesis, Oxford Unversity

Davies,J.G. and Offord,R E (1985) Brochem. J., 231, 389-392.

Davies,J.G., Muir,A.V. and Offord,R E. (1986) Blachem. J., 240, 609-612.

Geiger,R., Geusen,K., Summ,H.D. and Langner,D. (1975) Hoppe-Seyler's Z. Physiol Chem, 356, 1635-1649.

Gregory,H. and Walton,P.L. (1976) Patent Application GB 1426061.

Halban,P A. and Offord,R.E. (1975) Brochem. J., 151, 219-225.

Halban, P A , Karakash,C, Davies,J.G and Offord,R.E (1976) Buochem. J., $160,409-412$.

Moody,A J , Stan,M.A., Stan,M. and Glreman,J. (1974) Horm. Metab Res., 6. $12-16$.
Monhara,K., Oka, T , Tsazuk, H , Tochuno,Y. and Kanaya,T (1980) Brochem. Biophys. Res Commun., 92, 396-402

Monshıme, T., Bradshaw, C G and Radziuk,J. (1985) Am. J Physiol, 248, E203-E208

Muir,A.V , Offord,R E and Davies,J.G. (1986) Bıachem. J., 237, 631-637

Offord,R.E (1969) In Dawson,R M.C. Elliot,D C., Elliott,W.H. and Jones, K M (eds). Data for Buochemical Research 2nd edn, Oxford University Press, Oxford, pp 525-535.

Offord,R.E. (1980) Semusynthenc Peptides and Proteins. J. Wley and Sons Ltd, Chichester, p. 103.

Rose,K., DePury,H and Offord,R.E (1983) Biachem. $J, 211,671-676$

Rose,K., Gladstone,J and Offord,R.E. (1984) Bıochem. $J, 220,189-196$

Schmit,E W. and Gattner,H -G (1978) Hoppe Seyler's Z Physiol Chem, 359, $799-802$.

Received on July 13, 1987, rewsed on September 19, 1987 
